\title{
Dimensions of empathy in relation to language
}

\section{Visapää, Laura Sinikka}

2016

Visapää , L S \& Herlin , M I 2016 , ' Dimensions of empathy in relation to language ' , Nordic journal of linguistics , vol. 39 , no. 2 , pp. 135-157 . https://doi.org/10.1017/S0332586516000111

http://hdl.handle.net/10138/321061

https://doi.org/10.1017/S0332586516000111

cc_by_nc_nd

acceptedVersion

Downloaded from Helda, University of Helsinki institutional repository.

This is an electronic reprint of the original article.

This reprint may differ from the original in pagination and typographic detail.

Please cite the original version. 
Ilona Herlin \& Laura Visapää

\section{Dimensions of empathy in relation to language}

Final version before proofs. Published in Nordic Journal of Linguistics 39(2), 135-157.

This article approaches the relationship between empathy and language, describing the ways in which different dimensions of empathy can be attested in naturally occurring interactional data. The authors adopt the definition of empathy as a multidimensional phenomenon: emotional contagion, as well as the cognitive and affective dimensions of empathy, are all understood to be central to the empathetic process. The article promotes the view that studying the relationship between empathy and language should be grounded in the analysis of real-life interactions. Language evolves in social interaction both phylogenetically and ontogenetically, and is not only an important product but also a means of human sociality. The authors suggest that the best approach for analyzing the empathylanguage interface combines the theoretical insights of cognitive grammar with the method of conversation analysis. The paper shows that when empathy is analyzed in natural conversation, we can do sequential and linguistic analysis of the ways in which affect is shown, and through a careful analysis of grammatical devices, offer an explanation of whether the displays of affect are derived from the other person's situation. By analyzing the complex ways in which the interactants orient to the different dimensions of empathy, the paper shows how linguistic analysis can give us concrete tools for forming a deeper understanding of how empathy takes place in real-life encounters.

Keywords affect, cognitive grammar, conversation analysis, emotional contagion, empathy, grammar, ground, intersubjectivity, troubles-telling

Corresponding author:

\section{Laura Visapää}

Department of Finnish, Finno-Ugrian and Scandinavian Studies P.O. Box 4, 00014 University of Helsinki, Finland laura.visapaa@helsinki.fi 


\section{INTRODUCTION}

In recent decades, there has been an upsurge in the study of empathy in several fields of science, especially in biology, anthropology, developmental psychology and social neuroscience. Biologists are rethinking the role of pro-social behavior in human evolution: whereas evolutionary studies have traditionally laid heavy stress on competitiveness, last decades have emphasized the role of co-operation and mutual help in the survival and development of the human species. It has been suggested that empathy functions as the key mechanism in understanding other people and cooperating in an intelligible manner; it can thus be seen as a core mechanism of intersubjectivity (Zlatev 2008:223).

According to the sociobiologist and anthropologist Hrdy (2009), the human ability to empathize and co-operate can be traced back to our model of co-operative reproduction. Human mothers typically parent more than one child at the same time: children can be born even once a year, but a child needs to be taken care of for many years after its birth. Hrdy suggests that the Homo sapiens could not have evolved if mothers had been required to raise the offspring on their own. Children of different ages needed to be cared for by other close members of the group as well, typically by close relatives, and this complicated and contingent form of child caring required both males and females to invest heavily in social skills for co-operation. Such behavior required empathy: the ability to take into account the actions and intentions of other individuals, as well as the will to co-ordinate actions jointly and to behave in a pro-social manner, for the benefit of others.

The developmental psychologist Tomasello's concept of cultural intelligence also stresses the importance of co-operation: all cultural evolution and the accumulation of knowledge has been made possible by the human ability to take others into account, to set mutual goals and co-ordinate joint activities. According to Tomasello et al. (2005), the ability to co-operate and have joint intentions sets humans apart from other species; this, on its part, has required an ability to read other individuals' intentions, as well as cultural learning. Foremost, it is made possible by the presumably unique ability and will that humans have for sharing psychological states. The ability to participate in joint actions has provided the setting for such forms of cultural cognition that we now see as essentially human. Furthermore, it has made possible the use of linguistic symbols in the construction of social norms and individual beliefs, as well as social interaction, social relations and social institutions. (Zlatev 2008:236,238; Enfield 2013:xviii.)

Within linguistics, the importance of empathy as a core mechanism of intersubjectivity has come to be studied only in recent years (Itkonen 2008, 2009; Zlatev 2008; Herlin \& Visapää 2011). Even within these studies it has mostly been approached in a theoretical way, e.g. with respect to the evolution of language. In this article, we wish to make a contribution to this discussion by exploring empathy both from a theoretical and empirical perspective. While the data is mostly analyzed using methodological tools of conversation analysis (CA), we will also make use of theoretical concepts of cognitive grammar (CG), such as the concept of ground (on combining CA with CG, see Etelämäki 
et al. 2009; Etelämäki \& Visapää 2014). In what follows, we will briefly discuss the ways in which cognitive linguistics and CA address issues related to language and empathy.

Inspired by phenomenology, cognitive linguistics approaches human beings and their relationship to language by stressing the bodily basis of experience-in-the-world. Human cognition is seen to depend fundamentally on the body and its neurophysiological mechanisms, as well as on bodily-based experience of the world (e.g. Lakoff 1983; Talmy 2000; Levinson 2003.) Cognitive linguistics can be seen to have a body-based theory of meaning, which describes cognition as inherently dependent on embodiment, the sensory and motorical systems of the body as well as the bodily experiences and interactions with the world (Violi 2007). A radical version of an embodied understanding of meaning can be found in Lakoff and Johnson (1999), who claim that the human cognition and language are organized through image-schematic model: our conceptual structure emerges with respect to spatial relations and the settings we find ourselves in, and in this way, the spatially constructed image schemas function as the tools with which we conceptualize all of our experience, e.g., through metaphoric extensions.

It has, however, become increasingly more common in cognitive linguistics to underline the fact that human interaction precedes all image schematic models. After its birth, the human child comes to be embraced not only by "the world" but also, and perhaps more essentially, by other human beings. Stressing this, Kimmel (2007) suggests that the cognitive theory of language should widen its perspective by exploring the inherent relationship between embodied intentionality, agentivity and the human self, and then focus on the "shared" and "distributed" essence of embodiment. Since all meaning is created in interaction, embodied experience can be understood only by investigating the ways in which perception is grounded in human sociality.

Studying the relationship between empathy and language should thus also be grounded in the analyses of real-life interactions. Language evolves in social interaction both phylogenetically and ontogenetically (Schegloff 1996; Zlatev 2008), and it is not only an important product but also a means of human sociality. In the words of Zahavi (2014:107),"'any convincing theory of social cognition should be able to account for our face-to-face encounters with others".

In our view, the best approach for analyzing empathy-language interface combines the theoretical insights of cognitive grammar (Langacker 1987, 2008) with the method of conversation analysis. We find that some concepts of $\mathrm{CG}$ are useful in analyzing the ways in which the empathetic sharing is related to the linguistic construal of the speech situation, but these tools do not give us access to the interactional side of the process. CA, on the other hand, analyzes human interaction in naturally occurring settings, where talk-ininteraction is understood as a form of joint action (Sacks 1992; Schegloff 2007). In this framework, language is treated as a vehicle for carrying out actions in interaction, and the interpretation of actions is seen to depend on the constantly renegotiated context. That is, no conversationalist can decide alone what the "meaning" of their turn is, or what it is that they are doing. Each next turn is interpreted as displaying an understanding of its prior turn: every "second" turn thus provides the speaker of the "first" turn an understanding of what 
is going on and, at the same time, renews the context for the talk to come. In this way, the conversation analytic method provides one with tools for scrutinizing mechanisms of intersubjectivity. Combining it with the cognitive tradition therefore offers a fruitful starting point for broadening the study of empathy to encompass interactional phenomena, which are, in fact, deeply intertwined with our more "general" cognitive capacities.

Although the study of subjective emotions has been scarce within CA (Peräkylä 2012:282-283), the notion of empathy comes up rather frequently (Jefferson 1984, 1988; Ruusuvuori 2005, 2007; Hepburn \& Potter 2007, 2012; Heritage 2011; Couper-Kuhlen 2012; Heritage \& Lindström 2012a; Voutilainen 2012; Kupetz 2013; Voutilainen et al. 2015). ${ }^{\text {i }}$ Due to the methodological principle of relying on the interpretations presented in the next turn, a considerable amount of attention has been given to the ways in which interactants react to each other's emotions (Peräkylä 2012:282-283), and empathetic reactions have thus fallen under the scope of CA. However, the concept tends to be used as if it was referring to an indivisible phenomenon; the complex nature of empathy is rarely discussed (cf. Heritage 2011; Kupetz 2013).

In this article, we suggest that the multidimensional nature of empathy should be studied in the context of natural conversation. Furthermore, we will suggest that combining the methods of CA and the theoretical insights of CG can help us better understand how we can get hold of the multidimensional and sometimes even evasive nature of empathy, as it unfolds in real-life encounters. In what follows, we will first go through the various definitions of empathy, as well as the way in which we understand empathy (Section 2). In Section 3, we analyze a troubles-telling sequence with the methods of CA, and then proceed to look at the same data through the lens of CG (Section 4). In the last section of the paper, we will present a summary our main findings.

\section{DEFINITIONS OF EMPATHY}

The definitions of empathy vary significantly across the fields, often with conflicting tones even within one discipline. Empathy is generally used to refer to the cognitively complex process in which one is able to stand in the shoes of another person: to understand their perspective, emotions and the situation they are in. For a long time, empathy was considered a distinctively human ability, but lately it has been suggested that some primates, especially chimpanzees, are able to behave in an empathetic manner, too (e.g. Koski \& Sterck 2010). It has been proposed that the ability to empathize requires the ability to distinguish between the self and the other, and it would thus require a theory of mind: an individual that can understand that other individuals have a consciousness, thoughts and feelings different from one's own (Hoffmann 2000; Blair 2005; Preston \& de Waal 2002; Tomasello 2003). (For a critical discussion on theory of mind, see Zahavi 2014:99-102).

A crucial question has been whether empathy should be described as primarily a cognitive or an affective phenomenon. Many psychologists have defined empathy as the ability to enter the other person's mind, as "the intellectual or imaginative 
apprehension of another's condition or state of mind" (Hogan 1969), or as a process of "entering another's world without prejudice" (Rogers 1975:4).

If we conceived of empathy as an ability to understand the other person's perspective, we could easily detect a display of empathy in the following excerpt:

(1) $(\operatorname{sg} .346)$

01 Kirsi: sis:, (0.4) omii henkilökohta\#sii juttuja\# mitkä niin\#ku\#,

PRT OWN-PAR-PL PRIVATE-PAR-PL THIS-PAR-PL THAT LIKE

I mean (0.4) own personal things that like

02 Saila: joo,

PRT

yea

$03 \quad($.

04 Kirsi: m, (0.4) käsittelyssäh, (0.4) kestää k(h) $\underline{a u}(h) a n$,

PRT PROCESS-NIMLZ-INE LAST-3SG LONG

$\mathrm{m},(0.4)$ in process $(0.4)$ will take a long time

05

06 Saila: joo.

PRT

yea

In this example, Kirsi is starting to share a troublesome experience: she is explaining her friends why she has not been able to participate in the events being talked about. She describes her experience with generic noun phrases (own personal things that like, in process $1.1,4)$ together with the so-called zero person construction (will take a long time). These constructions are grammatically unspecified with regard to whose experience is being talked about, although the context makes it clear that Kirsi is sharing her own experience. With these constructions, she can, however, open up her own experience recognizable to the other recipients (Laitinen 2006).

Saila responds to Kirsi's turn twice with the particle joo (1. 2, 6). Sorjonen (2001) suggests that when joo is used as a response to an affiliation-relevant utterance, such as the one Kirsi produces on line 1 and 4, it merely registers the prior utterance as understood but does not affiliate with it. The joo response is thus, in this context, a linguistic resource with which the participant registers the prior turn and shows acknowledgment of what has been said without treating the utterance as one to be affiliated with. (Sorjonen 2001:132.) If one were to define empathy as the ability to understand the other person's perspective, Saila's joo responses could be seen to be empathetic. As a matter of fact, if we accepted this as the 
full definition of empathy, any utterance that claims an understanding of the other person's turn in a coherent manner would fall under the notion of empathy.

Within psychology, a research line that stresses the affective component of empathy has been more influential than the one focusing on the cognitive side of the process. Rather than seeing empathetic experience as a process of understanding the other's perspective, it has thus underlined the centrality of feeling with the other. According to Stotland (1969), when empathizing, the recipient reacts in an emotional manner, because he or she perceives another person experiencing a certain emotion. This definition made the concept too wide, however, as it made it cover such emotions as pity and schadenfreude ('malicious pleasure'). Since the 1980s, careful conceptual differences have been established between different kinds of emotional reactions, especially with regard to whether an emotion involved in an empathetic experience is automatic, whether it is cognitively processed and whether it can be seen to be primarily oriented towards the self or the other. (SEP; Ruusuvuori 2005:205-206.) Today, several leading psychologists define empathy as a multi-level process, which requires emotional involvement in the other's feelings (Preston $\&$ de Waal 2002; Hoffman 2000; Singer 2006). In this view, empathy consists of a cognitive representation of the other's feelings but also of an emotional component. (Blair 2005; Preston 2007, Preston et al. 2007.)

An important part of this multidimensional process is the primary, automatic orientation to another person's emotional state, which is commonly referred to as emotional contagion. Emotional contagion is based on the functioning of mirror neurons, a sequence of events in which people transfer their emotions to others (Rizzolatti \& Graighero 2004; Arbib 2012). This kind of emotional experience is based on an automatized copying of the others' emotions: people can end up feeling the same emotions simply because of their physical proximity and the neurological processes thus activated: a smiling face makes one smile, laughter catches on easily, and euphoria and panic spread quickly. Unlike cognitively processed empathy, emotional contagion does not require an understanding of the other person as the source of the emotion; on the contrary, people often see such emotions as deriving from themselves (Scheler 1973:22). Emotional contagion has been used to explain, for instance, the process in which a baby starts to cry as a reaction to another baby's crying. The underlying assumption is that children of this age are not yet capable of distinguishing between the self and the other (Hoffman 2000:65; cf. Zahavi 2014), but that they start to imitate the emotional reactions of their surroundings. (Zlatev 2008:222-224; Hari \& Kujala 2009:466.)

In this article, we adopt the definition of empathy as a multidimensional process, in which all of the above mentioned dimensions are intertwined (see also Preston $\&$ de Waal 2002a; Hoffman 2000; Preston 2007). That is, the empathetic process includes an affective and a cognitive dimension as well as the dimension of emotional contagion. We find our position to be in line with that of Eisenberg \& Fabes 1990, who define an empathetic phenomenon as follows:

An affective response that stems from the apprehension or comprehension of an other's emotional state or condition, and that is similar to what the other person 
is feeling or would be expected to feel.

We thus understand empathetic phenomena as reactions to the other's emotional state or condition that involve both an affective and a cognitive side. Some kind of affective reaction stemming from the other's situation is always a requirement for a reaction to be empathetic. However, there also needs to be an understanding of the affect stemming from the other's situation; any displays of such an understanding is what we refer to as the cognitive side of the process. A less conscious orientation to the other, "mirroring", can, however, also function as a dimension of the affective side of the empathetic process. In this sense, we will operate with the same dimensions as discussed earlier in this section: 1) emotional contagion, 2) a cognitive dimension, 3) an affective dimension.

What is central to our approach is that we are dealing with a multidimensional phenomenon, where one of these dimensions can be foregrounded in a given context, and that the orientations to the dimensions can be attested in different combinations. Here, we agree with the conversation analyst Kupetz (2013:27), who states that "in order to account for the different types of resources which can be used to display empathy in social interaction, it may be useful to conceptualize empathy displays not only as displays of understanding the other person's emotional situation, but as displays that range from more affect-oriented -- to more cognition oriented comprehension". She also underlines an important fact that comes up clearly in our own data, too: the empirical correlates for affective and cognitive sides of empathy are not attestable as dichotomies, but they are constantly renegotiated in the unfolding of the sequences (Kupetz ibid.)

While we rely on an affect-oriented definition when analyzing the displays of empathy in interaction, we also want to underline the role of empathy as a crucial element of the larger intersubjective machinery at play in all interaction. In addition to observable affective displays, empathy can be seen as a key mechanism in understanding other people and co-operating in an intelligible manner (Zlatev 2008:223, Hrdy 2009; Zahavi 2014). Our linguistic ability is primarily based on joint activity as well as our ability to understand the other individual's perspective, intentions and emotions, and the core mechanism that enables this is our ability to empathize with the other (Zlatev 2008:223). Joint activity can thus be seen to rely on empathetic processing, irrespective of whether we actually display empathy or not. In this sense, empathy can be seen to be a key element in joint activity and language use: language and interaction 'forces' us to be empathetic to a certain degree, whether we give any signs of our relating to the others or not.

When approaching empathy from this perspective, it comes close to the definitions of intersubjectivity (cf. the way the concept is defined in this collection). For us, to highlight this larger understanding of empathy is to suggest that empathy does not only involve displays of affective and/or cognitive involvement, but that it is a key mechanism in the way that the participants manage joint activities and joint agency (see Enfield 2013:35). Although this idea needs to be developed further in another setting, we will briefly come back to the ways in which the construal of the ground (including the relationship of the participants) is related to the sharedness of the ongoing action (see Section 4). 


\section{THE DIMENSIONS OF EMPATHY IN LIGHT OF CONVERSATION}

We will now analyze an excerpt of conversational data to investigate the ways in which the dimensions of empathy are present in everyday interactional encounters and how this can elucidate our understanding of language-empathy interface. Some observations have been made about empathic 'devices' in the previous studies on conversations. CouperKuhlen (2012:126) has found out in her study on the affiliative responses on complaints stories that prosody is a "primordial" way of expressing empathy. Kupetz's (2013) indepth study of empathy describes various response types that can be seen to display empathy in affect-laden tellings of personal experiences. (On empathetic responses, see also Ruusuvuori 2005, 2007; Hakulinen and Sorjonen 2012; Voutilainen 2012.) While we find all these studies highly relevant and while we will adopt their sequential approach, in our analysis we want to underline the different dimensions of empathy and how they can be foregrounded and oriented to in different ways at different phases of interaction.

In the following analysis, we focus on activities and gestures and, especially, on the grammatical structures used when empathy is expressed. As Stivers (2008) has noted, when studying how storytellers convey stance and how their hearers respond to it and convey affiliation, no response type as such can be said to be affiliating (also CouperKuhlen 2012:114); what is crucial is the sequential context of the response. This is certainly true about grammatical structures involved in expressing empathy, too (see Kupetz 2013:22). In other words, while pointing to certain grammatical structures or response types we are not claiming that they are empathic as such. Our aim is rather to make some observations about the sequential contexts in which the different grammatical and prosodic features can be used in expressing different orientations to the dimensions of empathy.

Our data consist of an hour of video recorded, face-to-face conversation between two middle-aged Finnish women, Kati and Taru, who are celebrating New Year's Eve at Taru's. ${ }^{\text {ii }}$ They are sitting in armchairs, drinking champagne and talking about various matters. In the middle of the conversation, and starting the extract we are focusing on here, there is a troubles-telling sequence where Taru starts to complain about a strange rash in her hand. We will analyze this single conversation segment by segment, as we want to show in detail how the interaction unfolds; that is, instead of pointing out parts of the conversation where a certain dimension of empathy can be detected, we will go through the entire extract, highlighting the complex ways in which the dimensions come into play in different sequential contexts.

When the extract starts, Kati starts to talk about how she does not like to eat crayfish in wintertime, because her skin gets very dry $(1.1-7)^{\mathrm{iii}}$ :

(2) (sg.440)

01 Kati mulla (.) tulee (.) talvella =siks mä en sicp: 
I-ADE COMES WINTER-ADE THEREFORE I NEG-1

in the winter I get that's why I

02 talvella tykkää syödä rapuja kun to:ta: mulon

WINTER-ADE LIKE-3SG EAT CRAYFISH-PL-PAR BECAUSE PRT I-ADE HAVE-3SG

don't like to eat crayfish in the winter because I

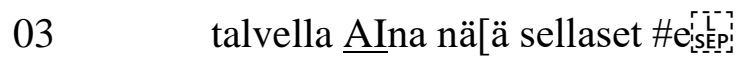

WINTER-ADE ALWAYS DEM LIKE

always have these like that in the winter

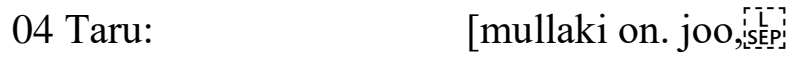

I-ADE-CLI HAVE-3SG PRT

me too. yea

05 Kati: .hh kuivat ja pahatis

DRY-PL AND BAD-PL

dry and bad

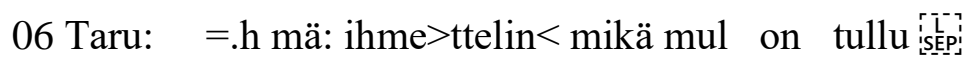

1SG WONDER-PST-1SG WHAT I-ADE HAVE-3SG COME-PAST

I was wondering what I have

07 niinku $<$ täältä $><$ kuivaa $>$ kato. .

PRT HERE-ABL DRY-PAR LOOK-IMP.

like it's so dry here you see.

08

09 Kati: >joo<. (0.8) .hhh (0.3) muon kaikki (.)

PRT I-ADE.3SG ALL

yea I have all

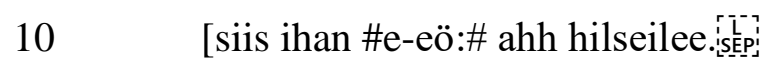

PRT PRT PEAL.OFF-3SG

like it \#e-eö:\# ahh peals off.

11 Taru: [siis mul on (.) mä \#\#o rannekellon heittäny is

PRT I-ADE HAVE-3 I BE-1SG WRISTWATCH-GEN THROW-PST

like I have (.) I have thrown my wristwatch

12 pọ:is $=\operatorname{kun}(0.2)>\operatorname{mmul}<($.$) m tiedä mistä,$

AWAY CONJ I-ADE KNOW-NEG WHERE 
away because I don't know where,

At the beginning of the extract, the women find out that they have experienced something similar: they both experience dryness of hands in the wintertime. Kati delivers her observation about the dry hands (1. 1-3), and Taru produces an overlapping turn in which she says that she shares the experience (1.4), followed by Kati's specification that her hands are "dry and bad" (1. 5).

Taru then repeats the fact that she has been wondering what she has on her own hands: she looks down to her hands and says that they feel very dry (1. 6-7). This turn is followed by a 0,5 seconds pause, followed by Kati's joo (1. 9), a recognition of what has been said. Kati does not encourage Taru to elaborate on her rash, but goes back to her own initial worry. Now, she uses an extreme case formulation (I have all, like it peals off, Pomerantz 1986; Sidnell 2004): she is still talking about the dryness of her hands, now reformulating that all of her skin is dry.

What becomes clear later in the conversation is that Taru is initiating a troublestelling sequence by calling attention to her rash. Here we refer to Jefferson (1984, 1988), who has shown the intricate ways in which the troubles-telling sequences are organized, calling attention to the ways in which the participants delicately navigate through these sequences by moving from business-as-usual to trouble and back. According to Jefferson (1988:420), troubles-telling consists roughly of the following segments: A) Approach, B) Arrival, C) Delivery, D) Work-Up, E) Close Implicature, F) Exit. In the extract seen above, Taru is producing turns that are ambiguous in their trouble-implicativeness; in fact Kati either fails to recognize the approach or, due to the ambiguous nature of Taru's turn, chooses to react to it in a neutral way, still keeping the possibility open for a "neutral" business-as-usual. (Jefferson 1988:422-423.) (For a detailed analysis of the same conversation as a troubles-telling sequence, see Etelämäki \& Visapää 2014:481-486.)

Nevertheless, when examining this extract from the perspective of empathy, the way in which the women mimic each other's movements becomes a focus of interest. When Kati first talks about her dry hands, she is looking down at them, moving them and rubbing them softly. Taru almost immediately starts to simulate these movements: she lifts her hands, starts to rub them and looks down at them. She is thus imitating Kati's movements, and then starts to talk about the irritating rash in her hands.

This could be used as a textbook example of mirroring, which might or might not lead to emotional contagion. As discussed previously, the mirror neuron system can makes us mimic each other's movements, expressions and emotional states. In the example discussed, mirroring seems to have an interactional consequence: the women first imitate each other's hand movements, and then end up negotiating whose experience will be the focus of talk. Although emotional contagion is hard to track through linguistic and interactional analysis - we cannot know whether the participants are 'really' emotionally synchronized -, we suggest that the ways in which participants imitate e.g. each other's behavior, body postures, prosody and linguistic structures can be a fruitful starting point for observing the synchronization involved in all empathetic understanding. 
(On resonance, see Du Bois \& Giora 2014; also Schegloff 1998.)

As the conversation continues, Taru describes her rash more specifically and announces the trouble (1. 11-14) (see Jefferson 1988:424-423). Here, Kati drops her own project and leans over to Taru and produces an announcement response (1. 15), which by displaying empathy, commits her as a troubles-recipient (see Jefferson 1998:425):

11 Taru: [siis mul on (.) mä \#\#o rannekellon heittäny ǐL

PRT I-ADE HAVE-3 I BE-1SG WRISTWATCH-GEN THROW-PST

like I have (.) I have thrown my wristwatch

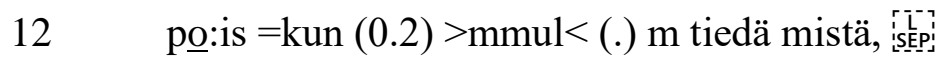

AWAY CONJ I-ADE KNOW-NEG WHERE

away because I don't know where,

13 mä en tiedä mistä tää taas on tullu

I NEG-2SG KNOW-NEG WHERE DEM AGAIN BE-3 COME-PST

I don't know where this has come from again

14 tämmös[t ihme (pahaa).

(Kati leans forward

to better look at Kati's hand)

THIS.KIND-PAR PRT BAD-PAR

this kind of like weird bad

15 Kati: [se on ihan pahana? herrajjümala

DEM BE-3G PRT BAD-ESS LORD.GOD

it's really bad oh my god

$16 \mathrm{ku}$ se on paha.is[ep]

CONJ DEM BE-3SG BAD

it's so bad.

We can thus see how the troubles-telling sequence is arrived at and responded to in an empathetic way. We suggest that Kati's turn shows an empathetic orientation to the trouble at hand in a both cognitive and affective manner. First of all, the lexical choices in Kati's turn are affective as such, but it is the prosody in her turn - the turn is produced with a whispering sound - and the way in which she leans closer to look at Taru's hand that suggest affective involvement. (Cf. Jefferson's 1988:420.) The cognitive orientation to the fact that this affect stems from the other's situation can best be explain with respect to pronouns. By using the demonstrative tää in line 13, Taru offers her rash as an observable and interpretable object (Etelämäki 2009:34); it is at this point that Kati leans forward to 
look at it more closely. With the pronoun tää Taru also indicates that she has primary access to the symptoms in her hand: when she refers to her hand and her worry with täa and tämmöst, she marks it to be her subjective experience that she is sharing with the other (Etelämäki ibid.). When Kati then produces her response it is quite bad oh my god it's bad (1. 15-16), she uses the pronoun se, which construes the hand as known enough for present purposes (Etelämäki 2009:34). The worry about the hand is now a shared, known referent for both of the interactants, and Taru's rash has become the shared object of concern.

Taru continues to describe the symptoms more carefully and thus moves to the exposition phase of the sequence (1. 18-19). According to Jefferson (1998), the exposition is typically followed by "affiliative turns" ("with expressions of "empathy", p. 42). Here, however, Kati gives advice: Taru should go and see a doctor (1. 20).

18 Taru: >n< vähän aikaa. hetken oli poissa ja iscept

SOME TIME-PAR MOMENT-GEN BE-3SG-PST AWAY AND

for some time now. for a moment it was gone and

19 ny[t taas

NOW AGAIN

now again

20 Kati: [käy lääkäris näy[ttämäs, [íspep]

GO-IMP DOCTOR-INE SHOW-3INF-INE

go show it to the doctor

21 Taru:

[mä oon käyny

I BE-1 GO-PST

I have been

22

eikä se osan[nu sanoo mitään:

NEG-3SG 3SG CAN-PST SAY-INF ANYTHING

eikä s/he wasn't able say anything

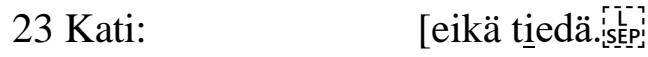

NEG-3G KNOW-INF

eikä doesn't know

Kati delivers her advice by using an imperative construction käy lääkäris näyttämäs (go show to the doctor, 1. 20). With the imperative, she can be seen to impose her own perspective to suggest an action that Taru controls (see Lauranto 2013:181). She does thus not adopt Taru's perspective but rather gives advice, which as such instantiates an asymmetry between the advice giver and the recipient (see Heritage \& Lindström 
2012b:170). Her turn could, in other words, be seen to have a pro-social, sympathetic motivation that aims to help the other, but it cannot be considered to be empathetic.

Taru responds by saying that she has already visited the doctor but that he or she didn't 'have anything to say' (1. 21-22). Kati responds to this turn with a subjectless third person construction eikä tiedä (doesn't know) (1. 23). After the advice seen in the previous excerpt, she is now producing an "affiliative response" to Taru's exposition (Jefferson 1998:428). Jefferson considers this to be typically the emotionally hightened segment of the troubles-telling sequence. Kati's turn is interpreted in an affective way due to its sequential position, and through linguistic analysis, we can see how she adopts Taru's perspective. Semantically, she reformulates Taru's turn: she produces a turn with an anaphoric person reference, where (an implied) third person 'does not know what's wrong'. The fact that she uses a subjectless third person construction echoes the perspective of Taru's turn: the subject of Kati's turn is interpreted to be the same as that of Taru's; Kati has thus syntactically adopted Taru's perspective. Although Kati's turn is syntactically similar to Taru's and it adopts its subject, she changes the tense from past to present, thus marking her affiliation's relevance for the ongoing moment. Her turn thus orients both to the affective and cognitive dimensions of empathy. Also, the fact that Kati designs her turn to echo Taru's turn can be seen as an example of the synchronization of grammatical structures (see also Du Bois \& Giora 2014), possibly related to emotional contagion.

After this, Taru reformulates what she has said before: although she went to the doctor, it is not exactly that the doctor didn't have a diagnosis but that she has not remembered to call for the results (1. 24-25):

22 eikä se osan[nu sanoo mitään

NEG-3SG 3SG CAN-PST SAY-INF ANYTHING

eikä s/he wasn't able say anything

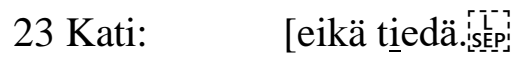

NEG-3G KNOW-INF

eikä doesn't know

24 Taru: =tai se $(\mathrm{v})$ otti verikokeet $>$ mut mäen o 0

OR 3SG TAKE-PST BLOOD.TEST-PL BUT I NEG-1 BE

I mean s/he took bloodtests but I haven't

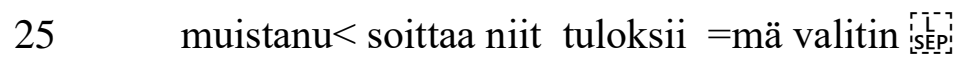

REMEMBER-PST CALL-INF DEM-PAR RESULT-PL-PAR I COMPLAIN-PST-1

remembered to call for the results I was complaining about

26 koko kättä ku (.) tämä, .hhhhh ja sitte 
WHOLE HAND-PAR PRT DEM AND THEN

the whole arm because this .hhhh and then

27 ku tätä jomottelee pitkin \#täältä\# ja,

CONJ DEM-PAR HURT-3SG ALONG HERE-ABL AND

because this hurts all the way here and

$28 \quad(3.7)$

29 Taru: e- ei taas nyt just. mut et jossai vaihees iste-pi

NEG NEG PRT NOW RIGHT. BUT PRT SOME POINT-INE

n- not right now. but like at some point

30 aina niingu (.) niinku koko käsi on sellane\#.s[epep

always like like whole hand is like.that

it always like like the whole arm is like

$31 \quad(1.4)$

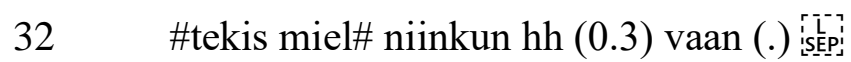

FEEL.LIKE-3SG LIKE JUST

you just feel like (0.3) like (.)

33 kietoa se johonki [villaan ja \#(antaa olla)\#is[i-p]

WRAP-INF DEM SOME-ILL WOOL-ILL AND LET-INF BE-INF

wrapping it in something like wool and let it be

34 Kati: [toittavast toi ei liity nyt

HOPEFULLY DEM NEG BE.CONNECTED PRT

hopefully it is not connected

35 jotenki: si[ihen

SOMEHOW DEM-ILL

somehow to that

36 Taru: $\quad[\mathrm{mnii} \mathrm{m}[\mathrm{m} \mathrm{m}$

jea $\mathrm{mmmm}$

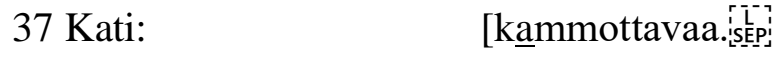

DREADFUL-PAR

dreadful

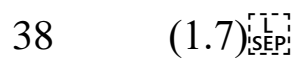


What becomes of special interest here are the body positions and the gaze of the women. Throughout her lengthy exposition (1. 24-33) Taru mostly looks down, changing her position, touching her hand and arm, whereas Kati sits like a Sphinx, leaning back, looking at Taru without a break (cf. Sacks 1984; Rossano 2012:310; see also Ruusuvuori \& Peräkylä 2009), not moving or reacting in any way. In line 28, Taru's reaction shows that a response is indeed missing: after 3.7 seconds, she raises her gaze from her hands to quickly look at Kati. When Kati still does not move or say anything, Taru continues to describe her symptoms. After another long pause (1.4 seconds) in line 31, Taru again takes the turn, this time describing how she feels like wrapping the hand in something woolen. Here, Kati produces an overlapping turn toivottavast toi ei liity nyt jotenkin siihen ('hopefully it is not connected to'), a diagnostic turn that she does not finish. Taru shows, however, with her response nii mm $m$ (1. 36) that she orients to shared knowledge; she claims to recognize the scenario implied in Kati's turn, and the women are thus diagnosing the rash together. The lexical choice of Kati's next turn kammottavaa ('dreadful'), as well as the way in which the turn is prosodically produced, displays strong affect and suggests that the shared knowledge refers to something unpleasant. As the pronoun toi in Kati's turn (1.34) construes a shared access to the referent and as Taru does not deny the diagnosis and affect displayed in Kati's turns, both the cognitive and affective dimensions of empathy are oriented to. ${ }^{\text {iv }}$

\section{THE LINGUISTIC CONSTRUAL OF THE GROUND AND THE DEGREE OF EMPATHETIC SHARING}

Next, we look at the same conversation from a cognitive grammar perspective, paying attention to the construal of the ground. In CG, ground is the term for speech event, including its immediate physical circumstances (place and time) as well as the participants and their shared knowledge (Langacker 1987, 1999). We are especially interested in whether the ground is symmetrically or asymmetrically construed, since it has been suggested that the more symmetrical its construal, the more it offers a place for a shared, affective perspective, as the participants (speaker $\&$ recipient) merge as a single conceptualizer (Etelämäki \& Visapää 2014).

The process where linguistic expressions are linked to the ground is called grounding. Languages have a set of elements for this purpose, grounding elements. Grounding elements are thus the means for specifying the relation between the expression and the speech situation (Langacker 1999: 219-220). These include tense markers, pronouns, demonstratives, and particles. In what follows, we focus on the use of demonstratives (tämä 'this', se 'it'), tenses and pronouns and the ways in which they construe the relation between the participants, the utterance, and the speech event.

While mainstream CG analyzes the grounding of individual NPs (ungrounded $d o g$ vs. grounded the dog) or finite clauses (to speak vs. grounded he speaks), produced 
by a single speaker who construes the ground by him/herself, our starting point is that the ground is dynamically co-construed (Etelämäki et al. 2009; Etelämäki \& Visapää 2014: 493-495; also Langacker 2014). What is of interest, then, from the perspective of empathy and 'feeling together', is to what degree the participants conceptualize the ground and themselves as part of the expression, and how they open up places for other interlocutors.

The two other concepts of CG we need to bring up are the notions of subjectivity and objectivity. These concepts call attention to the role of observation by highlighting whether an entity has a role as an object or subject of observation. When an entity is construed objectively, it is the focus of attention; when it is construed subjectively, it remains implicit, and has a role as part of the observation process. Langacker (2008:77) illustrates this an analogy: when one wears glasses, the glasses are part of one's visual system and therefore subjectively construed and non-salient. The glasses become salient, however, when taken off the nose, looked at and thus construed objectively.

Similarly, the ground can be construed objectively or subjectively in a linguistic expression. The ground gets objectified when deictic expressions that make specific reference to the speech event are put 'onstage', that is, when they are profiled in the expression. Expressions that focus attention to the aspects of ground - such as the participants (1. and 2. p. pronouns), the place of the speech event (e.g. here) or the time of speaking (the temporal adverb now) - construe the ground objectively. Ground can also be activated with less explicit grammatical markers - grounding predications (in English, e.g. tense, articles and demonstratives). Here, some aspect of the ground functions as the reference point of the utterance without being explicitly mentioned; it is thus construed more subjectively. The third group are non-deictic elements that include no conventionalized indexical reference to the speech situation (e.g. table, between); this is what is referred to as the maximally subjective construal of the ground. (Langacker 1999: 219-220.)

When the ground is objectively construed by e.g. 1. and 2. personal pronouns, the conceptualization of the participants becomes asymmetrical: with the pronoun $I$, it is the currently speaking participant that profiles him/herself in the ground as the focus of attention. Similarly, even the more subtle ways of referring to the ground always suggest an asymmetrical construal of the ground (Etelämäki \& Visapää 2014). Conversely, the less a turn is grounded, the less an expression posits grammatical asymmetries between the participants; that is, the construal is open for a fleeting "shared" perspective, and it can thereby invite shared understandings of the evaluated situations.

What we would like to suggest is that there could be a correlation between the linguistic construal of the ground and the degree of empathetic sharing between the interactants: on the basis of our observations, the more symmetrical the ground between the participants, the more the participants are 'feeling together'. The construal of the ground could thus provide one solution to the me-us problem pointed out by Enfield (2013), a solution that shows how the separateness and boundedness of the participants is navigated through grammatical means. 
Let us revisit the data. From the perspective of construal, the first phase of the conversation can be seen in 1. 1-14. In the entirety of this extract, both participants profile themselves as part of their turns using first person pronouns (e.g. mä 'I' in Taru's turns 1. 6, 11, 13 mullon 'I have'; Kati 1. 2, Taru 1. 4). They thus explicitly objectify themselves in the ground. They both also objectify their hand as part of the ground, putting it onstage as the focus; however both are markedly talking only about their own hands. From the perspective of grounding, the participants can be seen to construe themselves in a maximally asymmetrical way; both underline their own perspective on the matter. This is further supported by the use of the demonstrative pronoun tämä in Taru's turn in line 13, as well as Kati's nää (plural from of tämä) in line 3; Etelämäki (2009) has shown that tämä typically indexes that the speaker has a primary access to the referent.

The way in which the participants profile themselves as parts of their expressions changes in 1. 15: here Taru's hand becomes the primary object of concern for both participants. In lines 15-16, Kati produces a turn (se on ihan pahana herrajjumala ku se on paha, 'it is quite bad oh my god it's bad'), where the ground is more symmetrically organized. Here, the object of concern is referred to with the pronoun se, which indexes that the referent is symmetrically accessible to both participants (Etelämäki 2009). After this, however, Kati uses the imperative construction to give advice to Taru: with the imperative verb, she profiles the interaction of the speaker and hearer onstage, but does this markedly from her own perspective. In Taru's response I have been to the doctor she profiles herself in the utterance, contesting Kati's suggestion by saying that she has already done what Kati's turn advice told her to do.

The perspectives merge again in 1.23 when Kati produces the turn eikä tied $\ddot{a}$ ('doesn't know') as a response to Taru's turn (1. 22) eikä se osannu sanoo mitään ('s/he wasn't able say anything'). Here, Kati builds the interpretation of her anaphoric utterance on what Taru has said before, and the personal reference of the turn is interpreted with respect to the ground construal of Taru's turn. Interestingly, though, Kati uses the present tense unlike Kati, which positions the temporal reference of the utterance somewhat differently with respect to the ground, objectifying the present moment and thus marking the affiliation's relevance for the ongoing action.

After this, Taru produces a longer telling about visiting the doctor, and when Kati reacts to this $(1.34,37)$, she construes her turns again in a symmetrical fashion: first using the pronoun tuo ('that') in toivottavasti tuo ei nyt liity siihen and then, in line 37, producing the adjectival phrase kammottavaa, which can be seen to be maximally subjective in Langackerian terms. As this free-standing phrase (kammottavaa, 'dreadful') is grounded only by the larger indexical setting of the ongoing action, it construes the ground in a maximally symmetrical way, thus offering a place for a shared perspective and affect (Etelämäki \& Visapää 2014:492-493).

Our analysis of construing the ground and finding its connections to the ways in which the participants are 'feeling together' needs to be elaborated further. We hope to have shown, however, how the ways in which the sequences unfold has its reflection also in the grammatical organization of the ground. Whereas empathy can undoubtedly also be displayed with grammatical structures that profile the participants in an asymmetrical 
position (e.g. 'I feel for you', 'I think your situation is horrible'), our data invites us to see how moments of empathetic sharing are often built on a symmetrical construal of the ground.

\section{DISCUSSION}

In this article, we have approached the relationship between empathy and language, especially aiming at discussing the ways in which the different dimensions of empathy can be attested in naturally occurring interactional data. Also, we have tried to show what tools linguists have in analyzing such phenomena; in doing this, we have combined theoretical notions of cognitive grammar with the methodology of conversation analysis. Our main points can be summarized as followed:

Empathy is a multidimensional and complex phenomenon. All of its dimensions emotional contagion, cognitive and affective dimension - are central to the empathetic process. For a phenomenon to be empathetic, it needs to have an orientation to both the cognitive and affective dimensions of the process. We have shown how the methods of CA and the theoretical insights of CG can help us better understand the empathy-language interface. When analyzing natural conversation, we can do sequential and linguistic analysis of the ways in which affect is shown (the affective dimension of empathy), and through a careful analysis of the grammatical devices, offer an explanation of whether the displays of affect are shown to be derived from the other person's situation (the cognitive dimension of empathy). It is important to see how the dimensions can be foregrounded in different ways: sometimes the cognitive dimension is highlighted, sometimes the affective dimension, and due to this it might be hard to see how all of the dimensions are always at work in empathetic moments. Analyzing the complex ways that these dimension are oriented to, linguistic analysis can give us concrete tools for forming a deeper understanding of how empathy happens in real-life encounters.

In this article, we have also wanted to underline the pervasive nature of empathy in all language use and interaction. In addition to observable affective displays, empathy can be seen as a key mechanism in understanding other people and co-operating in an intelligible manner. Studying the architecture of everyday interactions shows in a tangible way how all intersubjective understanding requires empathetic involvement.

In our view, if we want to do justice to the complex nature of empathy, various complementary accounts have to be integrated. In this article, we have presented one possible theoretical and methodological combination. Here, by combining the methodology of CA with the theoretical insight of CG, we have shown that it is through language, gaze, body and other conventionalized interactional practices that we can enact and display empathy. Furthermore, the concept of empathy cannot and should not be analyzed as a unitary, indivisible phenomenon: it consists of several dimensions, which are constantly 
renegotiated. Consequently, empathy cannot be seen only as a characteristic of individual constructions or turns but it takes place in the interaction between the participants.

\section{REFERENCES}

ARBIB, MiCHAEL. 2012. How the brain got language. The Mirror System Hypothesis. Oxford: Oxford University Press.

BLAIR, JAMES. 2005. Responding to the emotions of others: dissociative forms of empathy through the study of typical and psychiatric population. - Consciousness \& Cognition 14(4), 698-718.

Couper-Kunlen, Elizabeth. 2012. Exploring Affiliation in the Reception of Conversational Complaint Stories. - Anssi Peräkylä \& Marja-Leena Sorjonen (eds.), 113-146.

Croft, William. 2009. Toward a social cognitive linguistics. - Vyvyan Evans \& Stéphanie Pourcel (eds.) New directions in cognitive linguistics, 395-420. Amsterdam: John Benjamins.

DARwall, STEPHEN. 1998. Empathy, Sympathy, Care. - Philosophical Studies 89 (2-3), 261282.

DU BOIS, JOHN \& RACHEL GIORA 2014. From cognitive-functional linguistics to dialogic syntax. - Cognitive Linguistics 25(3): 359-410.

EISENBERG, NANCY \& RICHARD A. FABES. 1990. Empathy: Conceptualization, measurement, and relation to prosocial behavior. In Motivation and Emotion, Vol 1:2, 131-149.

ENFIELD, NiCK. 2013. Relationship thinking. Agency, enchrony and human sociality. Oxford: Oxford University Press.

ETELÄMÄKI, MARJA. 2009. The Finnish demonstrative pronouns in light of interaction. Journal of Pragmatics 41 (2009), 25-46.

ETElämÄKI, MARJA \& Herlin, Ilona \& JAAKOla, MinNA \& VisAPÄÄ, LAURA. 2009: Kielioppi käsitteistyksenä ja toimintana. Kognitiivista kielioppia ja keskustelunanalyysia yhdistämässä. - Virittäjä 113, 162-187.

ETELÄMÄKI, MARJA \& VISAPÄÄ, LAURA 2014. Why blend cognitive grammar with conversation analysis? - Ritva Laury, Marja Etelämäki \& Elizabeth Couper-Kuhlen (eds.), Pragmatics: Approaches to Grammar for Interactional Linguistics 24:3.

GALLESE, VitTORIO. 2003. The manifold nature of interpersonal relations: the quest for a common mechanism. - Philosophical Transactions of the Royal Society of London B: Biological Sciences 358,1431, 517-528.

Hakulinen, Auli \& SorJonen, MarJa-LeEnA. 2012. Being Equivocal. Affective Response Left Unspecified. - Anssi Peräkylä \& Marja-Leena Sorjonen (eds.), 147-173.

HANKS, William. 1996. Language and communicative practices. Boulder, Colorado: Westview Press.

HARI, RitTtA \& KuJAla, MiIAmAaria. 2009. Brain Basis of Human Social Interaction: From Concepts to Brain Imaging. - Physiol. Rev 89: 453-479.

Hepburn, AleXA. 2004. Crying: notes on description, transcription, and interaction. - 
Research on Language and Social Interaction 37, 251-290.

Hepburn, Alexa \& Potter, Jonathan. 2007. Crying Receipts: Time, Empathy and Institutional Practice. - Research on Language and Social Interaction 40 (1), 89-116.

— 2012. Crying and Crying Responses. - Anssi Peräkylä \& Marja-Leena Sorjonen (eds.), 195-211.

HeRITAGE, JoHn. 2011. Territories of knowledge, territories of experience: Emphatic moments in interaction. - Stivers, Tanya, Lorenza Mondada \& Jakob Steensig (eds.), The Morality of Knowledge in Conversation, 159-183. Cambridge: Cambridge University Press.

Heritage, John \& ANNA LindSTRÖM. 2012a. Knowledge, Empathy, and Emotion in a medical encounter. - Anssi Peräkylä \& Marja-Leena Sorjonen (eds.), 256-273.

2012b. Advice giving - terminable and interminable: The case of British health visitors. - Holger Limberg, Miriam A. Locher (eds.), Advice in Discourse: 169-194. Amsterdam: John Benjamins Publishing Company.

Herlin, IlONA \& LAURA VisAPÄÄ. 2011. Mitä on empatia ja mikä sen suhde kieleen? Herlin, Ilona, Emmi Laukkanen, Jutta Salminen, Maria Mäkinen \& Laura Visapää (eds.), Kieli ja empatia, 7-28. University of Helsinki.

Hoffman, M. L. 2000. Empathy and Moral Development. Cambridge: Cambridge University Press.

Hogan, Robert 1969. Development of an empathy scale. - Journal of Consulting and Clinical Psychology 33, 307-316.

HRDY, SARAH. 2009. Mothers and others: the evolutionary origins of mutual understanding. Cambridge, Mass.: Belknap Press of Harvard University Press.

ITKONEN, ESA. 2008. Concerning the role of consciousness in linguistics. - Journal of Consciousness Studies 15/6, 15-33.

2009. The true nature of typological linguistics. - J. Zlatev \& al. (eds.), Studies in language and cognition. Newcastle: Cambridge Scholars Publishing.

JEFFERSON, GAIL. 1984. On stepwise transition from talk about a trouble to inappropriately next-positioned matters. - Maxwell J. Atkinson \& John Heritage (eds.), Structures of social action. Studies in Conversation Analysis, 191-223. Cambridge: Cambridge University Press.

1988. On the Sequential Organization of Troubles-Talk in Ordinary Conversation. Social Problems Vol. 35 No. 4, 418-441.

KiMMEL, MichAEL. 2007. Properties of cultural embodiment: Lessons from the anthropology of the body. - R. Frank \& R. Dirven \& T. Ziemke \& E. Bernardez (eds.), Body, language and mind vol 2, 77-108. Berlin: Mouton de Gruyter.

KOSKI, SONJA E. \& EliSABETH STERCK. 2010. Empathic chimpanzees: a proposal of the levels of emotional and cognitive processing in chimpanzee empathy. - European Journal of Developmental psychology (Vol. 7/1: Special issue on theory of mind).

KUPETZ, MAXI. 2013. Empathy displays as interactional achievements - Multimodal and sequential aspects. - Journal of Pragmatics 35 61:4-34 
LAITINEN, LEA. 2006. Zero person in Finnish: a grammatical resource for construing human reference. - Lyle Campbell \& Marja-Liisa Helasvuo (eds.), Grammar from the human perspecvtive: Case, space, and person, 209-231. Amsterdam: Benjamins.

LAKOFF, GEORGE. 1990. The Invariance hypothesis. Is abstract reason based on imageschemas? - Cognitive Linguistics 1(1), 39-74.

LAKOFF, GEORGE \& JoHnSON, MARK. 1980. Metaphors We Live By. Chicago: The University of Chicago Press.

1999. Philosophy in the flesh: the embodied mind and its challenge to Western thought. New York: Basic Books

LANGACKER, RONALD W. 1987. Foundations of cognitive grammar I: Theoretical Prerequisites. Stanford: Stanford University Press.

1999. Grammar and conceptualization. Cognitive Linguistics Research 14. BerlinNew York: Mouton de Gruyter.

2008. Cognitive Grammar. A basic introduction. Oxford: Oxford University Press.

2014. Subordination in a dynamic account of grammar. Visapää, Laura \& Jyrki Kalliokoski \& Helena Sorva (eds.), Contexts of Subordination. Amsterdam: John Benjamins.

LAURANTO, YRJÖ. 2013. Suomen kielen imperatiivi - yksi paradigma, kaksi systeemiä. Virittäjä 117, 156-200.

Levinson, Stephen. 2003. Space in Language and Cognition. Cambridge: Cambridge University Press.

PERÄKYLÄ, ANSSI. 2012. Epilogue. What does the Study of Interaction offer to Emotion Research? - Peräkylä \& Sorjonen (eds.), 274-289.

PERÄKYLÄ, ANSSI \& SORJONEN, MARJA-LEENA (eds.). 2012. Emotion in interaction. Oxford: Oxford University Press.

Pomerantz, ANiTA. 1986. Extreme Case Formulations: A Way of Legitimizing Claims. Human Studies 9:219-29.

PRESTON STEPHANIE. 2007. A perception-action model for empathy. - Farrow \& P Woodruff (eds.), Empathy in Mental Illness, 428-447. Cambridge: Cambridge University Press.

Preston, StePhanie \& DEWAAL Frans. 2002. Empathy: Its ultimate and proximate basis. Behavioral Brain Science 25 (1), 1-20.

RIZZOLATTI, GiACOMO \& GRAighERO, LAILA. 2005. Mirror neuron: a neurological approach to empathy. - Research and Perspectives in Neurosciences 2005, 107-123.

Rogers, CARL R. 1975. Empathic: 'An Unappreciated Way of Being' - The Counceling Psychologist 5(2), 2-10.

Rossano, Federico. 2012. Gaze in Conversation. - Sidnell, Jack \& Stivers, Tanya (eds.), The Handbook of Conversation Analysis: 308-329. Wiley-Blackwell.

RuUSuVuORI, JoHANNA. 2005. "Empathy" and "Sympathy" in Action: Attending to Patients' Troubles in Finnish Homeopathic and General Practice Consultations. - Social Psychology Quarterly Vol. 68, 204-222.

2007. Managing affect: integration of empathy and problem-solving in health care encounters. - Discourse Studies 9(5), 597-622.

RUUSUVUORI, JOHANNA \& PERÄKYLÄ, ANSSI. 2009. Facial and Verbal Expressions in 
Assessing Stories and Topics. - Research on Language and Social Interaction 42(4), 377-394.

SACKS, HARVEY. 1992. Lectures on Conversation (G. Jefferson ed.). Oxford: Blackwell. SCHELER, MAX. 1973. Wesen und Form der Sympathie. Bern/München, Francke Verlag. SCHEGloff, EMANUEl A. 1998. Body Torque. - Social Research Vol. 65, No. 3.

- 2007. Sequence organization. A primer in conversation analysis. Vol 1. Cambridge: Cambridge University Press.

SEP = STANFORD ENCYClOPEDIA OF PhILOSOPHY. 2010. Stanford University. http://plato.stanford.edu/entries/empathy. Read 1.11.2010.

SINGER, TANIA 2006. The neuronal basis and ontogeny of empathy and mind reading: Review of literature and implications for future research. - Neurosci Biobehav Rev. 30, 855863.

SORJONEN, MARJA-LEENA. 2001. Responding in conversation. A study of response particles in Finnish. Amsterdam: Benjamins.

Stivers, TANYA. 2005. Stance, Alignment, and Affiliation during Storytelling: When Nodding is a Token of Affiliation. - Research on Language and Social Interaction 41(1), 31-57.

STOTLAND, EzRA 1969. "Exploratory Investigations of Empathy." - L. Berkowitz (ed.), Advances in Experimental Social Psychology, vol. 4, 271-314. New York/London: Academic Press.

TALMY, LEONARD. 2000. Toward a cognitive semantics. Vol. I-II. Cambridge (MA): MIT Press.

TOMASEllo, Michael. 2003. Constructing a language: a usage-based theory of language acquisition. Cambridge (MA): Harvard University Press.

Tomasello, Michael \& Malinda CARPenter \& Josep Call \& TANya Behne \& Henrike MOLLY. 2005. Understanding and sharing intentions: The origins of cultural cognition. - Behavioral and Brain Sciences (2005) 28, 675-735.

VIOLI, PATRICIA. 2003. Beyond the body: Towards a full embodied semiosis. - Frank, Roslyn M., René Dirven, Tom Ziemke \& Enrique Bernardez (eds.), Body, language and mind, 241-264. Berlin: Mouton de Gruyter.

Voutilainen, LiISA. 2012: Responding to emotion in cognitive psychotherapy. Anssi Peräkylä \& Marja-Leena Sorjonen (eds.), 235-255.

Voutilainen, LiISA \& Anssi PERÄKYlÄ \& JOHANNA RuUSUVUORI. 2015: Sharing the Emotional Load: Recipient Affiliation Calms Down the Storyteller. - Social Psychology Quarterly, Vol. 78(4) 301-323.

ZahaVi, DAn. 2014. Self \& Other. Exploring subjectivity, empathy, and shame. Oxford: Oxford University Press.

ZLATEV, JORDAN. 2008: The co-evolution of intersubjectivity and bodily mimesis. - J. Zlatev, T. Racine, C. Sinha \& E. Itkonen (eds.), The shared mind: Perspectives on intersubjectivity, 215-244. Amsterdam: Benjamins.

Zlatev, Jordan \& Timothy Racine \& Chris Sinha \& EsA ITKOnen. 2008. Intersubjectivity: What makes us human? - J. Zlatev, T. Racine, C. Sinha \& E. Itkonen 
(eds.), The shared mind: Perspectives on intersubjectivity, 1-14. Amsterdam: Benjamins.

${ }^{i}$ Similar phenomena have been discussed under different terminology. The most used concepts are alignment or affiliation, the latter of which comes close to our definition of empathy. According to Sorjonen (2001), alignment shows that you understand what the other person says, whereas affiliation requires emotional, affective involvement. In a similar vein, Couper-Kuhlen (2012:113) defines affiliation as "the display of support and endorsement for a conveyed affective stance". Stivers (2008), on the other hand, uses the concepts somewhat differently, stressing that alignment should be understood as alignment with the other person's action, whereas as an affiliative turn is emotionally empathetic with the action. See also Kupetz 2013:6-9.

ii The data comes from the Conversational Data Archive at the University of Helsinki, and the abbreviations used (sg.440) refer to the code name of the conversation.

iii Assumed cultural knowledge is that you eat crayfish with your hands.

${ }^{\text {iv }}$ Kati seems to be behaving almost 'like a therapist', refusing a reaction in order to make the other speak. She does not display empathy, but a better description might be that she is being non-

empathetically empathetic. Instead of displaying empathy, she is oriented to making her friend go and see a doctor. 